\title{
AN ANALYTICAL STUDY ON IMPULSE BUYING FOR ONLINE SHOPPING DURING COVID-19
}

\author{
Shaifali Chauhan \\ Assistant Professor, Prestige Institute of Management, Gwalior, Madhya Pradesh, India and \\ Research Scholar, Department of Management, SOS, Jiwaji University, Gwalior, M.P. \\ Richa Banerjee \\ Assistant Professor, Prestige Institute of Management, Gwalior, Madhya Pradesh, India \\ Mohit Mittal \\ Inria Lille - Nord Europe, CRISTAL, France
}

\begin{abstract}
This study highlights the role of utilitarian shopping, hedonic shopping, and online advertisement on cognitive dissonance. Impulse Buying plays a role as a mediator in this research. The objective of this research is to investigate how utilitarian shopping value, hedonic shopping value, and online advertising influence the cognitive dissonance of customers. 338 response data have been collected from consumers involved in fashion apparel; respondents are majorly from central zone of India. Partial least square (PLS) - Structural equation modelling (SEM) is implemented using Smart PLS 3.0. The simulation result shows that utilitarian shopping value, hedonic shopping value, and online ads are found to be important in predicting cognitive dissonance and impulse buying, whereas impulse buying is impeccable in terms of predicting positive relationships with cognitive dissonance. Moreover, Impulse buying is playing as positive mediating effect in relation with constructs. Hence, this research suggests that a complex representation which may better understanding about consumer shopping behaviour. Conclusively, this research's major contribution towards authors' knowledge, and help the marketing expert to focus on important parameter of consumer buying behaviour.
\end{abstract}

Keywords: Online Advertisement, Shopping Values, Fashion Apparel, Cognitive Dissonance, PLS SEM, COVID-19.

\section{INTRODUCTION}

From past two decades, a technological era has started and engulfed every field that directly relates to human's life. With the advancement in the technology, the life is also becoming more easier with the increase in usage of machines and life-style is dependent on automation. This is not only restricted to arms industry, food and agriculture industry, chemical industry but also related to marketing field. This is mobilized more with the help of internet. Nowadays, internet is very easy and cost-effective technology for communication among the continents. There is very easy way to communicate and trade between different part of globe. The whole world is rejoiced over achievement of internet and developed many applications. The ecommerce is now big area for import and export products from various countries and delivered to specified place.
This is just far from on-click order and you will get the product. The online shopping industry is now selling their product directly to customer and recommend their other products directly via websites. A customer can now see various advertisements over various social media platforms where they can click on website and search the required products. Day by day online advertisements, social media recommending their products to customer depending on their point of interest (POI) which can be correlate with search history by using various tools. As this is included to bigdata analytic as the database is more than billions to trillions of terabytes space. With online shopping the industry can enhance their customer base with in few times depending on the requirement of the products in the current scenario and the brands create a big publicity over different platforms of social media to attract the customer. Initially, they provide limited number product to enhance 
their demand of their product and maintain supply-chain aspect. Intuitively, we can say that the interaction between individual customer with seller has increased through which big brands, fashion industry can relate to customers demand and grab their reviews towards their products. This is a great help for industry to manufacture product according to customer's requirement. For instance, Flipkart, amazon etc. online sites from where a customer can search their product and check the various reviews given by other customers those who already brought and used the same product. On the basis of reviews and recommendation of the users, there is a rating of product is available that help a new customer to buy the product. In case of branding the product, advertisement is required in such case a platform is needed from where a huge number user covered.

Due to COVID-19, it is difficult to go out and see the product offline and buy. So, the advertisement industry needs a smart play to cover their loses and encourage the customer to buy their products. Advertisement industry has collaborated with the various online platforms and social media networks to advertise their product. For instance, YouTube videos, Facebook, other websites are recommending the products depending on the site. On the other hand, these sources of advertisement generate the urge to buy products impulsively. Impulse buying is an unplanned decision to purchase a good or service taken immediately before purchase (Stern, 1962). Consumers who typically want to make such transactions are referred to as impulse buyers. Many studies show that sentiments and emotions play a very significant part in the purchasing process, triggered by a promotional sight or access to a well-heated advertising message (Park et al., 2006). Companies and retailers aim to take advantage of these desires that are exploit in the essential need to be immediately satisfied.

In context of psychology, people feel distress or unease due to cognitive dissonance (McGregor et al., 2001). Conflicts do occur in beliefs, ideas, or standards that are typically inspired by certain new knowledge, since people retain two or more unique beliefs, ideas, or values at the same period (Pajares, 1992). Leon Festinger (1957) invented the term cognitive dissonance, perhaps one his theories explains how an individual attempts to monitor or focus on his internal consistency. If anyone experiences uneasiness, they strive to minimize the triggers behind the uneasiness or seek to remove the cause of discomfort (Allyn and Festinger, 1961).

This research focuses on understanding several major factors that affect the acquisition of impulses and cognitive dissonance. Many of the research have clarified the influence of the purchasing of impulses on cognitive dissonance. None of the research identified any association between online advertisement, utilitarian shopping

value, hedonic shopping value and cognitive dissonance in a mediation with impulse buying. This research contributes to the understanding of how online advertising, shopping value mediating construct (impulse buying) influence cognitive dissonance.

\section{LITERATURE REVIEW \\ Utilitarian shopping value, Impulse Buying, Cognitive Dissonance}

Most previous studies have concentrated on the utilitarian dimensions of shopping (Bloch and Bruce 1984). Utilitarian consumption behavior has been defined as work-related and logical (Sherry, 1990; Batra and Ahtola, 1991; Engel et al., 1993). Utilitarian shopping value can depend on whether a specific consumption needs to stimulate a shopping trip, which has been achieved. It also implies that the commodity is purchased in a planned and productive manner. It was represented shopping with a working mindset (Hirschman and Holbrook 1982) and can be useful in describing the "darkness of shopping" referred to above. For instance, the utilitarian value may help understand why customers who consider shopping as "women's work" are going through what they believe is an involved process. Fischer and Arnold (1990) provide a classic example of this kind of buying. This shopper will only find the value if the buying activity is performed successfully or satisfactorily. In addition to this, Babin et al. (1994) identified no substantial correlation between impulsive buying and hedonic and utilitarian value. Given the need for an individual (Abratt \& Goodey 1990), 25 percent of the respondents made impulsive buying. The research found a significant positive relationship between impulse buying and utilitarian value. Babin et al. (1994). 
Consumers gain utilitarian benefits whenever they obtain the necessary product.

On the other hand, the utilitarian value involves money value, comfort decision, and time savings. Chang et al. (2004) demonstrate that male respondents are more utilitarian than hedonic. Khare (2011) defines that hedonic and utilitarian market ideals from small towns affected their shopping attitude. Specifically, for clothing and accessories, impulse purchasing is connected to searching-Hedonically and psychologically (Park et al., 2006; Beatty \& Ferrell, 1998). Madhavaram \& Laverie (2004) show that the Internet stimulates searching e-tailer products for leisure that is hedonic searching and informational motives that are utilitarian searching. Moreover, Lee \& Lee (2003) have described utilitarianism as adversely linked to the purchase of impulsiveness while hedonic is favorably related, thus justifying the hedonic role in influencing buying behavior while online shopping (Lee et al., 2009). Based on previous research, the following hypothesis formulated, as mentioned below.

H1a: Utilitarian Value effect on Impulse buying

H1b: Utilitarian Value effect on Cognitive Dissonance

H1c: Impulse buying mediate utilitarian value and Cognitive Dissonance

\section{Hedonic shopping value, Impulse Buying, Cognitive Dissonance}

Hedonism can describe as the principle that pleasure is the highest value in a special or desirable lifestyle, eager for enjoyment (The Chambers Dictionary, 1993). Hedonism is all about happiness, joy and pleasure (Andrew, 2008; Tiwari et al., 2020). Customers' desire for enjoyment is a sensual imperative, such that with higher hedonics it draws customers' interest (Hirschman \& Holbrook, 1982). On the other hand, the consequences of hedonism on society may be detrimental. Additionally, an action-based model of dissonance says that people seek to strike a balance between aversive and consonant contradictory views (Jones, 1999). This may lead to such acts that are detrimental to mankind of hedonic. Also, hedonic consumption affects health because, in its own way, it is just for consumer satisfaction (Zhong \& Mitchell, 2010). Hedonic value is a dimension of consumer behaviour which specifically related to multisensory and emotional intake (Holbrook and Hirschman, 1982). Hedonic importance includes perceptual modality such as tact, taste, touch and sound, which include the imagination for creating emotional excitement (Tifferet and Herstein, 2012). Under these conditions, ever more items can be purchased by these individuals. Hedonic value tries, in a specific way, to fulfil the expressed demand for consumption, based on experience (Miller, 2000). The desire for hedonic value can be viewed as a technique which restraint that sensitive to a greater need for the user to enhance entertainment or to overcome a certain need (Gross, 2002). Since impulse buying is a way of psychological selfregulation, therefore expect both constructs to be positively related (Tifferet and Herstein, 2012). Babin et al. (1994) demonstrate that people have a more hedonistic orientation while they are in the leisure stage of purchase, and that they can behave in a more impulsive manner. Recreation tends to favor the purchasing of impulses, since recreation makes the person more desirable. Based on this the following hypothesis are framed:

H2a: Hedonic Value effect on Impulse buying

H2b: Hedonic Value effect on Cognitive Dissonance

H2c: Impulse buying mediate Hedonic value and Cognitive Dissonance

\section{Online Advertisement, Impulse Buying, Cognitive Dissonance}

Online advertising is a compensated way to connect (promotion) with consumers for a goods or services (Richards et al. 2002). It has long been in use for the marketing of goods and services. online advertisement is an effective and also most powerful way of communicating product information. It requires a great deal of emphasis for better communication. Advertising draws consumer interest, but not always Fitzgerald (1998) says that $90 \%$ of his advertisement is wasted and he doesn't know which part $90 \%$ is. If advertisement gains the consumers' attention due to the quality of the product or advertising itself, or for some other purpose, it still needs to be examined. The crux of the argument is that advertisement has a positive effect on the minds of consumers 
(Krishnamurthy, 2001; Martin et al., 2003). Similarly, Zhang et al. (2014) reported that online advertising can also play a key role in internet shopping. That is a method of communication which can help to measure behaviour patterns of social interaction, and also classified as observational learning (Zhang et al., 2014; Chen et al., 2011). It's based on knowledge of cascade theory (Bikhcandani \& Sharma, 2001). Previous study has established the variables that affect the purchasing of online impulses, including product image, banner ads, low prices and promotional deals (de Kervenoael et al., 2009). Many studies have explored online shopping impulse as either a state of mind or an intrinsic psychological trait (Wells et al., 2011; Shiva et al., 2020). Zhang et al. (2006), for instant, explained the importance of an individual's impulsiveness in their probability of buying online impulses. Furthermore, the environmental role of reflections i.e. online advertising on the probability of individuals purchasing online impulses were examined (Parboteeah et al., 2009; Wells et al., 2011). Based on this discussion the following hypothesis are framed:

H3a: Online Advertising effect on Impulse buying

$\mathrm{H} 2 \mathrm{~b}$ : Online Advertising effect on Cognitive Dissonance
H3c: Impulse buying mediate Online Advertising and Cognitive Dissonance

\section{Impulse buying, Cognitive Dissonance}

Current researchers suggest that impulse purchasing contributes to greater cognitive dissonance than the more structured purchase. The justification for this inference is derived from the present literature (Zaichkowsky, 1985). The individual Involvement leads to the research of how much time, energy, thought and other resources individuals spend on the buying process (Beatty and Kahle, 1988). It is a cognitive reaction that overcomes ambiguity. The consumer concerned looks for knowledge from inside, personal sources and media sources, such as catalogues, product reviews, consultants, etc., throughout the constraints of the situation, while making a purchase (Beharrell and Denison, 1995). Even so, impulsive buying as an action which can occasionally be seen by those who do not have elevated impulsive behavior. Comparatively high degree of enthusiasm and enjoyment felt by someone with high emotional instability which can also improve their post-purchase comparison tendency. As a result, they are more likely to regret the buying decision than others. It is noteworthy to note that, in market research, redemption also appears as a significant feature of an impulsive purchasing trait (Wood, 1998). The impulsiveness factor is also accompanied by a lack of self-control (Strack and Deutsch, 2004). This situation can

Figure 1: Conceptual Model

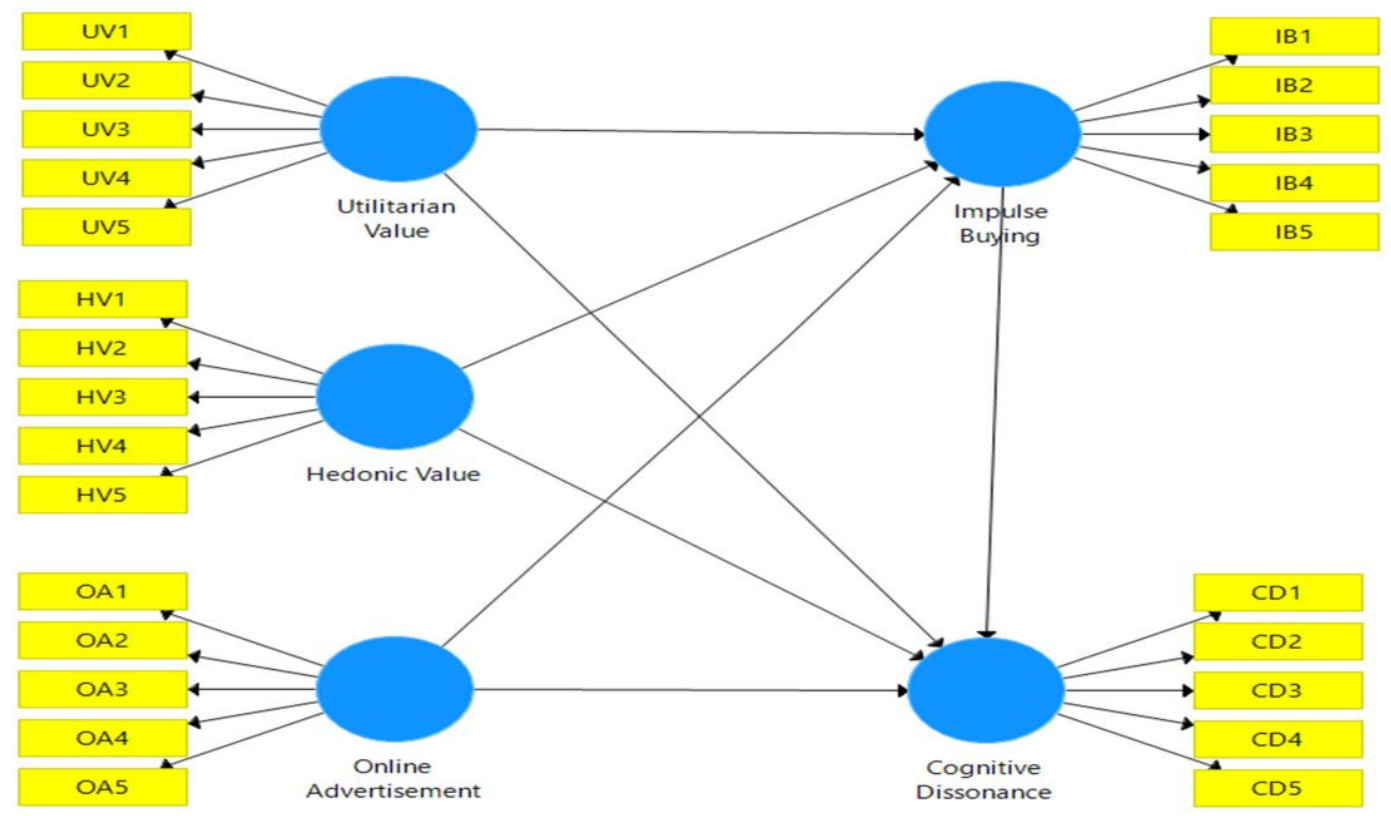


also apply to the post-purchase situation. If so, individuals with high impulsiveness may switch out to be such a category which is more vulnerable to cognitive dissonance. In other words, more influenced by the emotions can feel a greater level of cognitive dissonance than the others. On the basis of above discussion, the mentioned hypothesis is framed:

H4: Impulse Buying contributing significant effect on Cognitive Dissonance

Based on the above discussion the proposed conceptual model was prepared as mentioned below:

\section{RESEARCH METHODOLOGY}

The data for the study was gathered with the help of Google forms link for that non probability purposive sampling was used. In study 361 data was collected from respondents who are majorly involve in online apparel shopping. The responses were collected from major cities of central zone (Indore, Bhopal, Gwalior) of India out of which 23 responses were discarded as the responses were not complete. Final 338 valid responses were used for the data analysis. the respondents were mainly from the people of age group ranged between 18 years to 45 years. the surveys instrument which we used to measure the latent variables were adapted from previous studies and little changes were made according to the context of the study. To measure Cognitive dissonance the measure used was of Heitland and Bohner (2010), for hedonic value the instrument used was of Babine et al. (1994), for impulse buying standardized questionnaire of Rook and Hoch (1985) has been used, to measure utilitarian value scale of was used and to measure a Babine et al. (1994). Advertisement scale of Henthorne et al. (1993). All the items of the questionnaire were a 7-point likert scale measured from strongly disagree to strongly agree. The PLS-SEM was used for structural equation modeling purpose. The software was

Table 1: Reliability and convergent Validity

\begin{tabular}{|c|c|c|c|c|c|c|}
\hline \multicolumn{3}{|c|}{ Parameters } & $\begin{array}{c}\text { Cronbach's } \\
\text { Alpha }\end{array}$ & rho_A & $\begin{array}{l}\text { Composite } \\
\text { Reliability }\end{array}$ & AVE \\
\hline \multirow{5}{*}{$\begin{array}{l}\text { Cognitive } \\
\text { Dissonance }\end{array}$} & CD1 & 0.8 & \multirow{5}{*}{0.831} & \multirow{5}{*}{0.835} & \multirow{5}{*}{0.881} & \multirow{5}{*}{0.598} \\
\hline & CD2 & 0.742 & & & & \\
\hline & CD3 & 0.769 & & & & \\
\hline & CD4 & 0.808 & & & & \\
\hline & CD5 & 0.744 & & & & \\
\hline \multirow{5}{*}{ Hedonic Value } & HV1 & 0.747 & \multirow{5}{*}{0.762} & \multirow{5}{*}{0.774} & \multirow{5}{*}{0.84} & \multirow{5}{*}{0.514} \\
\hline & HV2 & 0.8 & & & & \\
\hline & HV3 & 0.72 & & & & \\
\hline & HV4 & 0.614 & & & & \\
\hline & HV5 & 0.69 & & & & \\
\hline \multirow{5}{*}{ Impulse Buying } & IB1 & 0.82 & \multirow{5}{*}{0.837} & \multirow{5}{*}{0.848} & \multirow{5}{*}{0.885} & \multirow{5}{*}{0.609} \\
\hline & IB2 & 0.814 & & & & \\
\hline & IB3 & 0.73 & & & & \\
\hline & IB4 & 0.656 & & & & \\
\hline & IB5 & 0.864 & & & & \\
\hline \multirow{5}{*}{$\begin{array}{c}\text { Online } \\
\text { Advertisement }\end{array}$} & OA1 & 0.673 & \multirow{5}{*}{0.799} & \multirow{5}{*}{0.813} & \multirow{5}{*}{0.862} & \multirow{5}{*}{0.556} \\
\hline & OA2 & 0.787 & & & & \\
\hline & OA3 & 0.783 & & & & \\
\hline & OA4 & 0.682 & & & & \\
\hline & OA5 & 0.793 & & & & \\
\hline \multirow{5}{*}{ Utilitarian Value } & UV1 & 0.763 & \multirow{5}{*}{0.816} & \multirow{5}{*}{0.832} & \multirow{5}{*}{0.871} & \multirow{5}{*}{0.575} \\
\hline & UV2 & 0.691 & & & & \\
\hline & UV3 & 0.805 & & & & \\
\hline & UV4 & 0.718 & & & & \\
\hline & UV5 & 0.807 & & & & \\
\hline
\end{tabular}

Source: Authors' Calculations 
used to measure Factor loadings, Cronbach's alpha reliability, AVE, discriminant validity, multicollinearity, causal relationship between independent variable and dependent variable as well as mediation analysis.

\section{DATA ANALYSIS}

Measurement Model Assessment

Confirmatory factor analysis was used to understand relation between the variables, factors and indicators. The model of the study consists of three independent variables i.e. hedonic value, online advertisement, utilitarian value. It has one mediating variable i.e. impulse buying and one independent variable i.e. cognitive dissonance. Table 1 is showing values for factor loadings, Cronbach's alpha reliability, composite reliability and Average variance extracted. All the factor loadings were significant providing support for convergent validity of the constructs, the Cronbach's alpha value for all the constructs is above 0.7 threshold value. The value of composite reliability and AVE is also higher than the minimum required value of 0.6 and 0.5 respectively for all the constructs.

To measure discriminant validity Fornell and Lacker criteria and HTMT was used (Hair et.al 2010; Fornell and Lacker 1981). Fornell Lacker criterion uses square root of AVE with the correlation of the latent variables. The value of the latent construct should explain the variance of its own indicator more than any other indicator. Table 2 shows value of Fornell and Lacker criterion value for each indicator and it shows that the latent construct has squared correlation value highest than any other indicator

Table 3 reports the results of HeterotraitMonotrait (HTMT) analysis value. HTMT is alternative approach of Fornell and Lacker. HTMT approach is suggested by Henseler et.al (2015) as Fornell and Lacker criterion does not detect discriminant validity. HTMT value reported in table 3 shows the estimate of inter construct correlation. All the values across the diagonal (in bold) are below 0.9 and hence acceptable. From both the criterion i.e. Fornell and Lacker and HTMT we can conclude that the correlations among the construct are in acceptable range and there in no collinearity issues.

\section{Assessment of Structural Model (Direct and Indirect Relationships)}

The analysis of VIF standards of latent variables should be done before hypothesis testing. The VIF standards below 3.33 (Diamantopoulos et al., 2008) suggest that the multicollinearity issues are not present in the study. The internal VIF value of the different latent constructs are 2.453 for hedonic shopping value, 1.660 for utilitarian shopping value, for online advertisement it is 2.754 , and 2.047 for impulse buying. The analysis consequently explains there were no issues with the collinearity (Hair et al., 2017).

Table 2: Fornell- Lacker Criteria

\begin{tabular}{|c|c|c|c|c|c|}
\hline & $\begin{array}{c}\text { Cognitive } \\
\text { Dissonance }\end{array}$ & $\begin{array}{c}\text { Hedonic } \\
\text { Value }\end{array}$ & $\begin{array}{c}\text { Impulse } \\
\text { Buying }\end{array}$ & $\begin{array}{c}\text { Online } \\
\text { Advertisement }\end{array}$ & $\begin{array}{c}\text { Utilitarian } \\
\text { Value }\end{array}$ \\
\hline Cognitive Dissonance & $\mathbf{0 . 7 7 3}$ & & & & \\
\hline Hedonic Value & 0.569 & $\mathbf{0 . 7 1 7}$ & & & \\
\hline Impulse Buying & 0.599 & 0.594 & $\mathbf{0 . 7 8 1}$ & & \\
\hline Online Advertisement & 0.665 & 0.489 & 0.522 & $\mathbf{0 . 7 4 6}$ & \\
\hline Utilitarian Value & 0.642 & 0.626 & 0.662 & 0.588 & $\mathbf{0 . 7 5 8}$ \\
\hline
\end{tabular}

Source: Authors' Calculations

Table 3: HTMT Matrix

\begin{tabular}{|l|c|l|c|l|l|}
\hline & $\begin{array}{l}\text { Cognitive } \\
\text { Dissonance }\end{array}$ & $\begin{array}{l}\text { Hedonic } \\
\text { Value }\end{array}$ & $\begin{array}{l}\text { Impulse } \\
\text { Buying }\end{array}$ & $\begin{array}{l}\text { Online } \\
\text { Advertisement }\end{array}$ & $\begin{array}{l}\text { Utilitarian } \\
\text { Value }\end{array}$ \\
\hline Cognitive Dissonance & & & & & \\
\hline Hedonic Value & $\mathbf{0 . 4 5 8}$ & & & & \\
\hline Impulse Buying & 0.554 & $\mathbf{0 . 4 8 8}$ & & & \\
\hline Online Advertisement & 0.526 & 0.586 & $\mathbf{0 . 6 8 6}$ & & \\
\hline Utilitarian Value & 0.759 & 0.767 & 0.785 & $\mathbf{0 . 7 1 4}$ & \\
\hline
\end{tabular}

Source: Authors' Calculations 
The following figure 2 the structural model of the study. The model assessed the hypothesis of the study about the direct and indirect relationships among the variables. The model assessed R2 (coefficient of determination, Q2 (cross validated redundancy), F2 (effect size). The model was assessed for direct relationships and mediating effect of Impulse buying.

Table 5 and figure 2 provides details of structural modeling. The results show that the direct relationship between Hedonic value, utilitarian value, online advertisement and impulse buying. The direct relationship between Hedonic value and cognitive dissonance is significant at $\mathrm{P}=0.00$, between hedonic value is significant at $\mathrm{P}=0.00$, between impulse buying and cognitive dissonance is significant $(\mathrm{P}=0.004)$, between online advertisement and cognitive dissonance is significant $(\mathrm{P}=0.00)$, between online advertisement and impulse buying is significant at $p$ value of 0.000 , between utilitarian value and cognitive dissonance is significant at $\mathrm{P}$ value of 0.002 and between utilitarian value and impulse buying is significant at $\mathrm{P}$ value of 0.00 . Hence the hypothesis $\mathrm{H} 1 \mathrm{a}, \mathrm{H} 1 \mathrm{~b}, \mathrm{H} 2 \mathrm{a}, \mathrm{H} 2 \mathrm{~b}, \mathrm{H} 3 \mathrm{a}, \mathrm{H} 3 \mathrm{~b}$ in direct relationship among constructs are found significant.

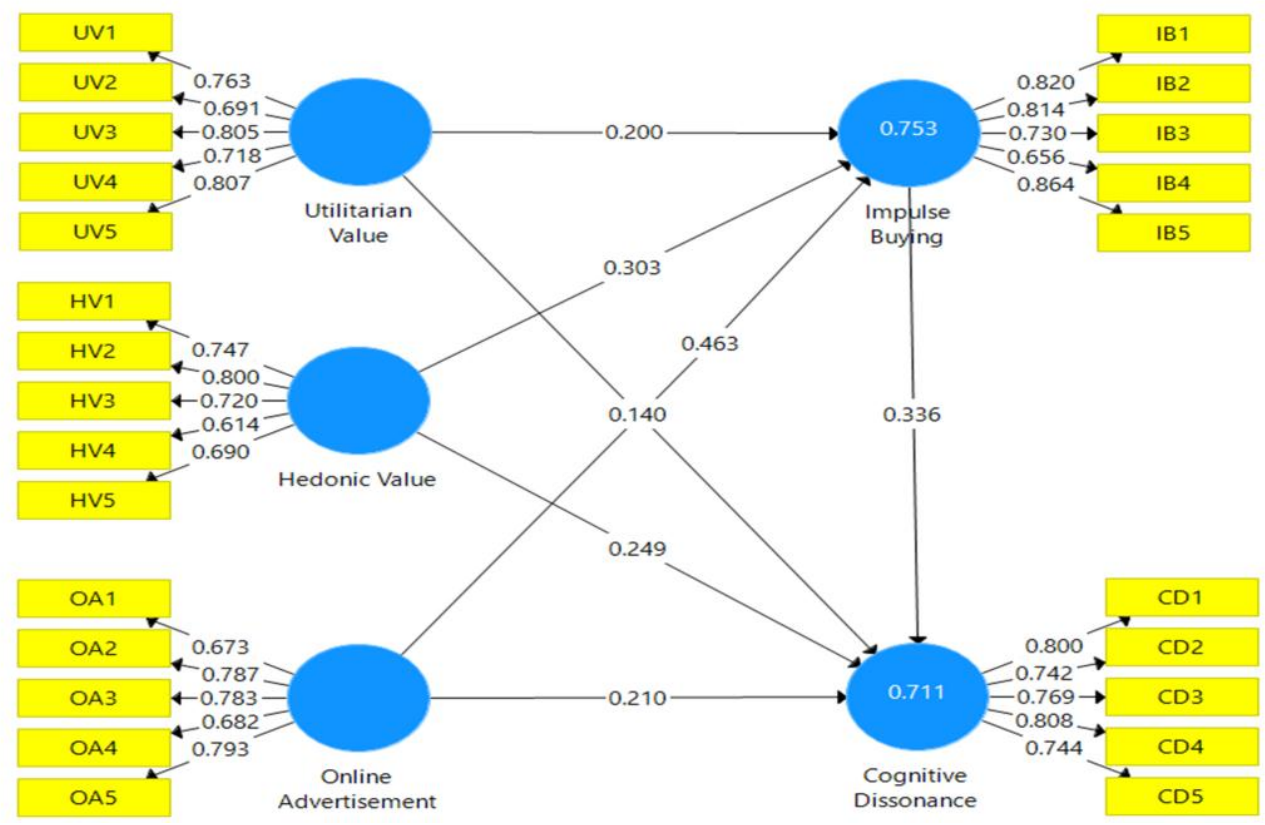

Table 5: Results of structural model

\begin{tabular}{|l|c|c|c|c|c|c|c|}
\hline & $\begin{array}{c}\text { Original } \\
\text { Sample } \\
(\mathbf{O})\end{array}$ & $\begin{array}{c}\text { Sample } \\
\text { Mean } \\
(\mathbf{M})\end{array}$ & $\begin{array}{c}\text { Standard } \\
\text { Deviation } \\
\text { (STDEV) }\end{array}$ & $\begin{array}{c}\text { T Statistics } \\
(\mid \text { O/STDEV |) }\end{array}$ & $\begin{array}{c}\mathbf{P} \\
\text { Values }\end{array}$ & $\mathbf{2 . 5 0 \%}$ & $\mathbf{9 7 . 5 0 \%}$ \\
\hline $\begin{array}{l}\text { Hedonic Value -> } \\
\text { Cognitive Dissonance }\end{array}$ & 0.249 & 0.251 & 0.061 & 4.059 & 0 & 0.125 & 0.364 \\
\hline $\begin{array}{l}\text { Hedonic Value -> } \\
\text { Impulse Buying }\end{array}$ & 0.303 & 0.303 & 0.05 & 6.121 & 0 & 0.206 & 0.4 \\
\hline $\begin{array}{l}\text { Impulse Buying -> } \\
\text { Cognitive Dissonance }\end{array}$ & 0.336 & 0.336 & 0.069 & 4.858 & 0 & 0.201 & 0.473 \\
\hline $\begin{array}{l}\text { Online Advertisement } \\
\text {-> Cognitive } \\
\text { Dissonance }\end{array}$ & 0.21 & 0.21 & 0.072 & 2.909 & 0.004 & 0.07 & 0.35 \\
\hline $\begin{array}{l}\text { Online Advertisement } \\
\text {-> Impulse Buying }\end{array}$ & 0.463 & 0.465 & 0.044 & 10.464 & 0 & 0.375 & 0.549 \\
\hline $\begin{array}{l}\text { Utilitarian Value -> } \\
\text { Cognitive Dissonance }\end{array}$ & 0.14 & 0.139 & 0.044 & 3.146 & 0.002 & 0.056 & 0.228 \\
\hline $\begin{array}{l}\text { Utilitarian Value -> } \\
\text { Impulse Buying }\end{array}$ & 0.2 & 0.199 & 0.035 & 5.752 & 0 & 0.13 & 0.266 \\
\hline
\end{tabular}

Source: Authors' Calculations 


\section{Mediating Relationship}

Table 6 is representing results of mediating relationships. Impulse buying is mediating variable in relationship of hedonic value, utilitarian value and online advertisement as independent variables and cognitive dissonance as dependent variable. The results show that impulse buying is mediating relationships between all the independent and dependent variables (1) relationship of hedonic value and cognitive dissonance is mediated by impulse buying, at $p$ value of 0.000 , (II) relationship of online advertisement and cognitive dissonance is mediated by impulse buying is significant at $\mathrm{P}$ value of 0.00, (III) Impulse buying is a mediator in relationship of utilitarian value and cognitive dissonance significant at $\mathrm{p}$ value of 0.000 . Hence Hypothesis H1c, H2c, H3c are supported empirically.

Table 6: Mediating relationships is 0.277 while the Q2 value of impulse buying is 0.321. At last, SRMR is a measure of approximate fit of the model. By convention, a model has good fit when SRMR is less than .08 (Hu \& Bentler, 1998). The SRMR value for the present model is 0.074 and value of NFI is 0.761 , chi square value is 1158.43 . Hence, the results are highly acceptable in the study.

\section{DISCUSSION}

\section{General Discussion and Conclusion}

In present Covid- 19 situation people of all age group are becoming more familiar with online shopping. Due to this covid condition people are facing problems to get update themselves with latest fashion trends. Fashion is considered as an important part of people life as they love to wear the latest fashion. So, the conceptual model is prepared on the basis of this current situation. The study implies the effect of shopping values and online

\begin{tabular}{|l|c|c|c|c|c|c|c|}
\hline & $\begin{array}{c}\text { Original } \\
\text { Sample } \\
\text { (O) }\end{array}$ & $\begin{array}{c}\text { Sample } \\
\text { Mean } \\
\text { (M) }\end{array}$ & $\begin{array}{c}\text { Standard } \\
\text { Deviation } \\
\text { (STDEV }\end{array}$ & $\begin{array}{c}\text { T Statistics } \\
\text { (|O/STDEV|) }\end{array}$ & $\begin{array}{c}\mathbf{P} \\
\text { Values }\end{array}$ & $\mathbf{2 . 5 0 \%}$ & $\mathbf{9 7 . 5 0 \%}$ \\
\hline $\begin{array}{l}\text { Hedonic Value -> } \\
\text { Impulse Buying -> } \\
\text { Cognitive } \\
\text { Dissonance }\end{array}$ & 0.102 & 0.102 & 0.026 & 3.89 & 0 & 0.057 & 0.161 \\
\hline $\begin{array}{l}\text { Online } \\
\text { Advertisement -> } \\
\text { Impulse Buying -> } \\
\text { Cognitive } \\
\text { Dissonance }\end{array}$ & 0.156 & 0.156 & 0.036 & 4.384 & 0 & 0.091 & 0.229 \\
\hline $\begin{array}{l}\text { Utilitarian Value - } \\
>\text { Impulse Buying } \\
\text {-> Cognitive } \\
\text { Dissonance }\end{array}$ & 0.067 & 0.067 & 0.019 & 3.524 & 0 & 0.036 & 0.11 \\
\hline
\end{tabular}

Source: Authors' Calculations

PLS SEM generate $\mathrm{R}^{2}$ value for the model. The range of $R 2$ is in between 0 and 1 and the value of R2 above 0.67 is considered as substantial predictive power (Chin, 2010). The model of the study is showing value of R2 for cognitive dissonance 0.711 , which explains 71.1 percent of the construct and for impulse buying it is 0.753 , which explains 75.3 percent of the construct. While Q2 value of greater than zero for a particular latent variable indicate the path model's predictive relevance for a specific dependent construct (Hair et al. 2016). The value of Q2 for the model should be more than Zero, the findings suggest strong effect as the Q2 value of cognitive dissonance advertisement on cognitive dissonance with mediating effect of impulse buying. Hence, the result revel that Hypothesis $\mathrm{H} 1 \mathrm{a}$ that is utilitarian effect on impulse buying and $\mathrm{H} 1 \mathrm{~b}$ that is utilitarian effect on cognitive dissonance found positive significant effect among the constructs results of these relations are supported by (Babin et al., 1994; Wasaya et al., 2016). The next relation is H2a i.e. hedonic shopping value effects on impulse buying and $\mathrm{H} 2 \mathrm{~b}$ i.e. hedonic shopping value effect on cognitive dissonance found impeccable relationship with the construct's relation. Results are supported by (Jones, 1999; Zhong \& Mitchell, 2010). Similarly, Hypothesis H3a 
i.e. online advertisement effect on impulse buying and $\mathrm{H} 3 \mathrm{~b}$ i.e. online advertisement effect on cognitive dissonance found positive significant effect among the constructs, outcome is supported by (Wood, 1998; Strack and Deutsch, 2004). H4 that is impulse buying in relation with cognitive dissonance found significant in the study. Result of this relation is supported by (Strack and Deutsch, 2004). In Addition to this, the study analyzed the mediating effect of impulse buying with utilitarian shopping value, hedonic shopping value, online advertising and cognitive dissonance. Hence, the results revel that H1c, $\mathrm{H} 2 \mathrm{c}, \mathrm{H} 3 \mathrm{c}$ are found positive mediating effect of impulse buying in relation with constructs. The outcome of all the relation are supported by (Wasaya et al., 2016). Therefore, the association of all the constructs has given a valuable in site to previous literature in relation with consumer shopping behaviour towards fashion apparels.

\section{Limitations and future scope}

There are definitely certain drawbacks that need to be addressed while analyzing these findings. Although the sample size was relatively small and the data was only collected from central zone of India. So, the findings cannot be generalized to the overall population within analysis. At the same time, due to the time constraint, no in-depth interviews were performed to collect further comprehensive results on consumer shopping behaviour. So, the study recommends to include the qualitative analysis which can give in-depth in site about the behaviour of the consumer during online shopping and also get knowledge about which factor is motivating consumer more for online purchase. On the other hand, the study has not use moderating variables which also effects the consumer shopping behaviour. Hence, the study recommends to apply moderating variables such as age, gender etc. to analyze the reason behind online impulse buying of consumers.

\section{Managerial Implication}

This report has some realistic implications. The results of this study show relationship between online advertisement on impulse buying as well as on cognitive dissonance this result can be used by advertisers. The advertisers should consider and respond to the growing value of online marketing and social media platforms for marketing because they impact consumer purchasing intentions and influence consumers to purchase impulses. The enterprises can consider adopting social media marketing and online marketing by actively tracking the concerns of customers and changing their internet marketing tactics.

Second the study concluded that both buyers and consumers undergo cognitive dissonance to some degree. Marketing managers must search at ways to reduce the cognitive dissonance generated, since cognitive dissonance is a precedent for consumer loyalty. Moreover, online marketing and social media can be used effectively to influence cognitive dissonance of consumers. Consumers too, on their own, try to minimize dissonance, even by defending a decision. Marketing administrators should then pursue those inherent efforts and reduce cognitive dissonance after the purchase. In this way the marketers can take guidance to aligning their efforts and policies towards consumer dissonance reduction and providing more value to the consumers.

\section{REFERENCES}

Abratt R and Goodey S D (1990), "Unplanned Buying and In-Store Stimuli in Supermarkets", Managerial and Decision Economics, Vol. 11, No. 2, pp. 111-121

Allyn, J., \& Festinger, L. (1961). The effectiveness of unanticipated persuasive communications. The Journal of Abnormal and Social Psychology, 62(1), 35.

Babin B, Darden WR, Griffin M. (1994) Work and/or fun: measuring hedonic and utilitarian shopping value. J Consum Res;20(4):644-56

Babin, B.J., Darden, W.R. and Griffin, M. (1994), "Work and/or fun: measuring hedonic and utilitarian shopping value", Journal of Consumer Research, Vol. 20 No. 4, pp. 644-656.

Batra, Rajeev and Olli T. Ahtola (1991), "Measuring the Hedonic and Utilitarian Sources of Consumer Attitudes," Marketing Letters, 2 ,159-170. 
Beatty SE, Ferrell ME. (1998) Impulse buying: modeling its precursors. J Retailing 1998;74(2): 169-91.

Beharrell, B. and Denison, T.J. (1995), "Involvement in a routine food shopping context", British Food Journal, Vol. 97 No. 4, pp. 24-9.

Bloch, Peter H. and Grady D. Bruce (1984), "Product Involvement as Leisure Behavior," in Advances in Consumer Research, Vol. 11, ed. Thomas C. Kinnear, Ann Arbor, MI: Association for Consumer Research, 197- 202.

Chang E, Burns LD, Francis SK. (2004) Gender differences in the dimensional structure of apparel shopping satisfaction among Korean consumers: the role of hedonic shopping value. Clothing Textiles Res J ;22(4):185-99.

De Kervenoael, R., Aykac, D.S.O. and Palmer, M. (2009) 'Online social capital: understanding e-impulse buying in practice', Journal of Retailing and Consumer Services, Vol. 16, No. 4, pp.320-328.

Engel, James F., Roger D. Blackwell, and Paul W. Miniard (1993), Consumer Behavior, Chicago: Dryden.

Festinger, L. (1957). A Theory of Cognitive Dissonance. Stanford, CA: Stanford University Press

Fischer, Eileen and Stephen J. Arnold (1990), "More than a Labor of Love: Gender Roles and Christmas Shopping," Joutrnal of Consumer Research, 17 (December), 333-345.

Gross, J.J. (2002), “Emotion regulation: Affective, cognitive, and social consequences", Psychophysiology, Vol. 39 No. 3, pp. 281-291.

Hair JF, Sarstedt M, Ringle CM, et al. (2018) Advanced Issues in Partial Least Squares Structural Equation Modeling (PLS-SEM), Thousand Oaks, CA: Sage

Hair, J F., Howard, M and Nitzl, C (2020). Assessing measurement model quality in PLS-SEM using confirmatory composite analysis. Journal of Business Research 109:101-110
Hair, J., Hollingsworth, C.L., Randolph, A.B. and Chong, A.Y.L. (2017), "An updated and expanded assessment of PLS-SEM in information systems research", Industrial Management \& Data Systems, Vol. 117 No. 3, pp. 442458.

Hair, J.F., Black, W.C., Babin, B.J. and Anderson, R.E. (2010), Multivariate Data Analysis, Prentice Hall, Englewood Cliffs, NJ

Hair, J.F., Sarstedt, M. and Ringle, C.M. (2019), Rethinking some of the rethinking of partial least squares", European Journal of Marketing, Vol. 53 No. 4, pp. 566-584.

Halbrook and Hircshman. (1982). The Experimental Aspects of Consumption: Consumer Fantasies, Feellings and Fun. Journal of Consumer Research, 132-140.

Hausman, A. (2000), “A multi-method investigation of consumer motivations in impulse buying behavior", Journal of Consumer Marketing, Vol. 17 No. 5, pp. 403-426.

Henseler J, Ringle CM and Sarstedt $M$. (2015) A New Criterion for Assessing Discriminant Validity in Variance-based Structural Equation Modeling. Journal of the Academy of Marketing Science 43(1): 115-135

Henseler, J. (2017). Bridging design and behavioral research with variance-based structural equation modeling. Journal of Advertising, 46(1), 178-192.

Henseler, J., Hubona, G.S. and Ray, P.A. (2016), Using PLS Path Modeling in New Technology Research: Updated Guidelines, Industrial Management \& Data Systems, Vol. 116, pp. 1-19.

Hirschman, E. C., \& Holbrook, M. B. (1982). Hedonic consumption: emerging concepts, methods and propositions. The Journal of Marketing, 92-101.

Heitland, K., \& Bohner, G. (2010). Reducing prejudice via cognitive dissonance: Individual differences in preferences for consistency moderate the effects of counter-attitudinal advocacy. Social Influence, 5(3), 164-181. 
Holbrook, M.B. and Hirschman, E.C. (1982), "The experiential aspects of consumption: consumer fantasies, feelings, and fun", Journal of Consumer Research, Vol. 9 No. 2, pp. 132-140.

Hu, L. T., \& Bentler, P. M. (1999). Cut off criteria for fit indexes in covariance structure analysis: Conventional criteria versus new alternatives. Structural Equation Modeling: A Multidisciplinary Journal, 6(1), 1-55

K.Z.K. Zhang, B. Hu, S.J. Zhao (2014) How Online Social Interactions Affect Consumers' Impulse Purchase on Group Shopping Websites, 18th Pacific Asia Conference on Information Systems (PACIS), Chengdu, China,.

Khare, Arpita (2011). Influence of hedonic and utilitarian values in determining attitude towards malls: A case of Indian small city consumers. Journal of Retail \& Leisure Property, 9(5), 429-442.

Krishnamurthy, S. (2001). A comprehensive analysis of permission marketing. Journal of Computer-Mediated Communication, 6(2).

Lee H, Lee H. (2003) The impacts of browsing on buying impulsiveness in Internet shopping malls. Korean Manage Rev, 32(5):1235-63.

Lee M, Kim Y, Fairhurst A. (2009) Shopping value in online auctions: their antecedents and outcomes. J Retail Consum Serv 2009;16(1):75-82.

Madhavaram SR, Laverie DA.(2004) Exploring impulse purchasing on the Internet. Adv Consum Res;31(1):59-66.

Martin, B. A. S., Durme, J. V., Raulas, M., \& Merisavo, M. (2003). Email advertising: exploratory insights from Finland. Journal of Advertising Research, 43(3), 293-300.

McGregor, I., Zanna, M. P., Holmes, J. G., \& Spencer, S. J. (2001). Compensatory conviction in the face of personal uncertainty: going to extremes and being one self. Journal of Personality and Social Psychology, 80(3), 472.
Miller, N.G. (2000), "Retail leasing in a web enabled world", Journal of Real Estate Portfolio Management, Vol. 6 No. 2, pp. 167-184.

Nitzl, C., Roldan, J. L., \& Cepeda, G. (2016). Mediation analysis in partial least squares path modeling: Helping researchers discuss more sophisticated models. Industrial Management \& Data Systems, 116(9), 1849-1864.

Pajares, M. F. (1992). Teachers' beliefs and educational research: Cleaning up a messy construct. Review of Educational Research, 62(3), 307-332.

Park EJ, Kim EY, Forney JC. (2006) A structural model of fashion-oriented impulse buying behavior. J Fashion Mark Manage;10(4):433-46.

Richards, J. I., \& Curran, C. M. (2002). Oracles on "advertising": Searching for a definition. Journal of Advertising, 31(2), 63-77.

Richter NF, Cepeda Carrión G, Roldán JL, et al. (2016) European Management Research Using Partial Least Squares Structural Equation Modeling (PLSSEM): European Management Journal 34(6): 589-597.

Rigdon, E.E. (2016), "Choosing PLS Path Modeling as Analytical Method in European Management Research: A Realist Perspective", European Management Journal, Vol. 34, pp. 598605.

Ringle CM and Sarstedt M. (2016) Gain More Insight from Your PLS-SEM Results: The Importance-Performance Map Analysis. Industrial Management \& Data Systems 116(9): 1865-1886.

Ringle, C.M., Sarstedt, M. and Schlittgen, R. (2014), "Genetic Algorithm Segmentation in Partial Least Squares Structural Equation Modeling", OR Spectrum, Vol. 36, pp. 251- 276.

Rook, D. W. (1987). The buying impulse. Journal of Consumer Research, 14(2), 189-199.

Rook, D. W., \& Hoch, S. J. (1985). Consuming impulses. Advances in Consumer Research, 12(1), 23-27. 
S. Bikhcandani, S. Sharma. (2001) Herd behavior in financial markets, IMF Staff Papers 47

Sherry, John F., Jr. (1990b), "Dealers and Dealing in a Periodic Market: Informal Retailing in Ethnographic Perspective," Journal of Retailing, 66 (Summer), 174200.

Shiva A., Narula S.\& Shahi S.K. (2020) What Drives Retail Investors' Investment Decisions? Evidence from No Mobile Phone Phobia (Nomophobia) And Investor Fear of Missing Out (I - Fomo). Journal of Content, Community \& Communication Vol. 11

Stern, H. (1962). The significance of impulse buying today. The Journal of Marketing, 59-62.

Strack, F. and Deutsch, R. (2004), “Reflective and impulsive determinants of social behavior", Personality and Social Psychology Review, Vol. 8, pp. 220-47.

Tifferet, S. and Herstein, R. (2012), “Gender differences in Brand commitment, impulse buying, and hedonic consumption", Journal of Product and Brand Management, Vol. 21 No. 3, pp. 176-182.

Tiwari, Mansi; Narula, Sumit; Mathur, Garima (2020). Looking-glass-self: Tale of happiness, self-esteem, and satisfaction with life among transgender from Kinner community. Journal of Public Affairs, doi:10.1002/pa.2519

Wells, J.D., Parboteeah, V. and Valacich, J.S. (2011) ‘Online impulse buying: understanding the interplay between consumer impulsiveness and website quality', Journal of the Association for Information Systems, Vol. 12, No. 1, pp.32-56.

Wood, M. (1998), “Socio-economic status, delay of gratification, and impulse buying", Journal of Economic Psychology, Vol. 19 No. 3, pp. 295-320.

Y. Chen, Q.Wang, J. Xie, (2011) Online social interactions: a natural experiment on word of mouth versus observational learning, Journal of Marketing Research 48, pp 238-254.

Zaichkowsky, J.L. (1985), “Measuring the involvement concept", Journal of Consumer Research, Vol. 12, December, pp. 341-52.

Zhang, X., Prybutok, V.R. and Koh, C.E. (2006) 'The role of impulsiveness on a TAM-based online purchasing behavior model', Information Resources Management Journal, Vol. 19, No. 2, pp.54-68.

Zhong, J. Y., \& Mitchell, V. W. (2010). A mechanism model of the effect of hedonic product consumption on wellbeing. Journal of Consumer Psychology, 20(2), 152-162. 